
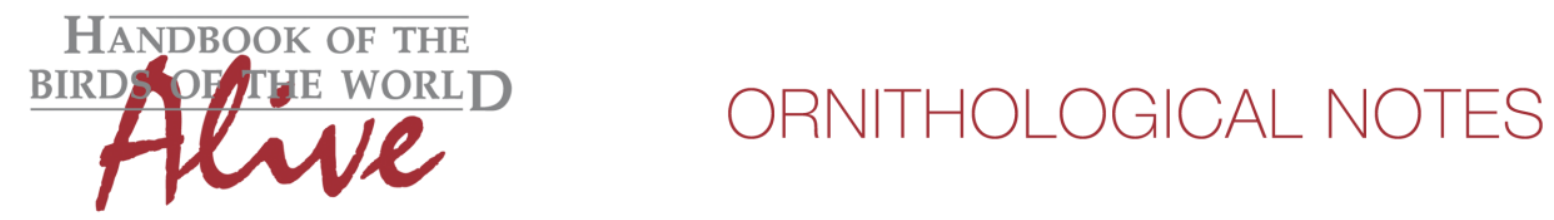

\title{
Notes on the vocalizations of Rough-legged Tyrannulet (Phyllomyias burmeisteri)
}

\section{Peter Boesman}

In the following we briefly analyze and compare voice of the different races of Rough-legged Tyrannulet (Phyllomyias burmeisteri). We also try to quantify the extent of any vocal differences using the criteria proposed by Tobias et al. (2010), as a support for taxonomic review. We have made use of sound recordings available on-line from Xeno Canto (XC).

Typical vocalization is a repeated single overslurred note "pseet". Less often, a faster series of similar notes is given (often slightly descending).

While structurally about identical, there are clearly 2 vocal groups based on basic sound parameters (Fig. 1):

Group 1: All races north of the Peruvian/Bolivian border $(n=9)$

Measurements:

Note length

0.22-0.37s (race zeledoni seemingly longest notes)

min. freq.

$4100-5200 \mathrm{~Hz}$

max. freq.

$6400-7100 \mathrm{~Hz}$

pace*

0.33-0.40s (for fast series)

Group 2: South and east of Peruvian/Bolivian border (burmeisteri) ( $\mathrm{n}=9$ )

Measurements:

Note length

$0.14-0.24 \mathrm{~s}$

min. freq.

$3100-3500 \mathrm{~Hz}$

max. freq.

$4900-5700 \mathrm{~Hz}$

pace

0.25-0.33s (for fast series)

* pace measured here as period, duration between two consecutive notes

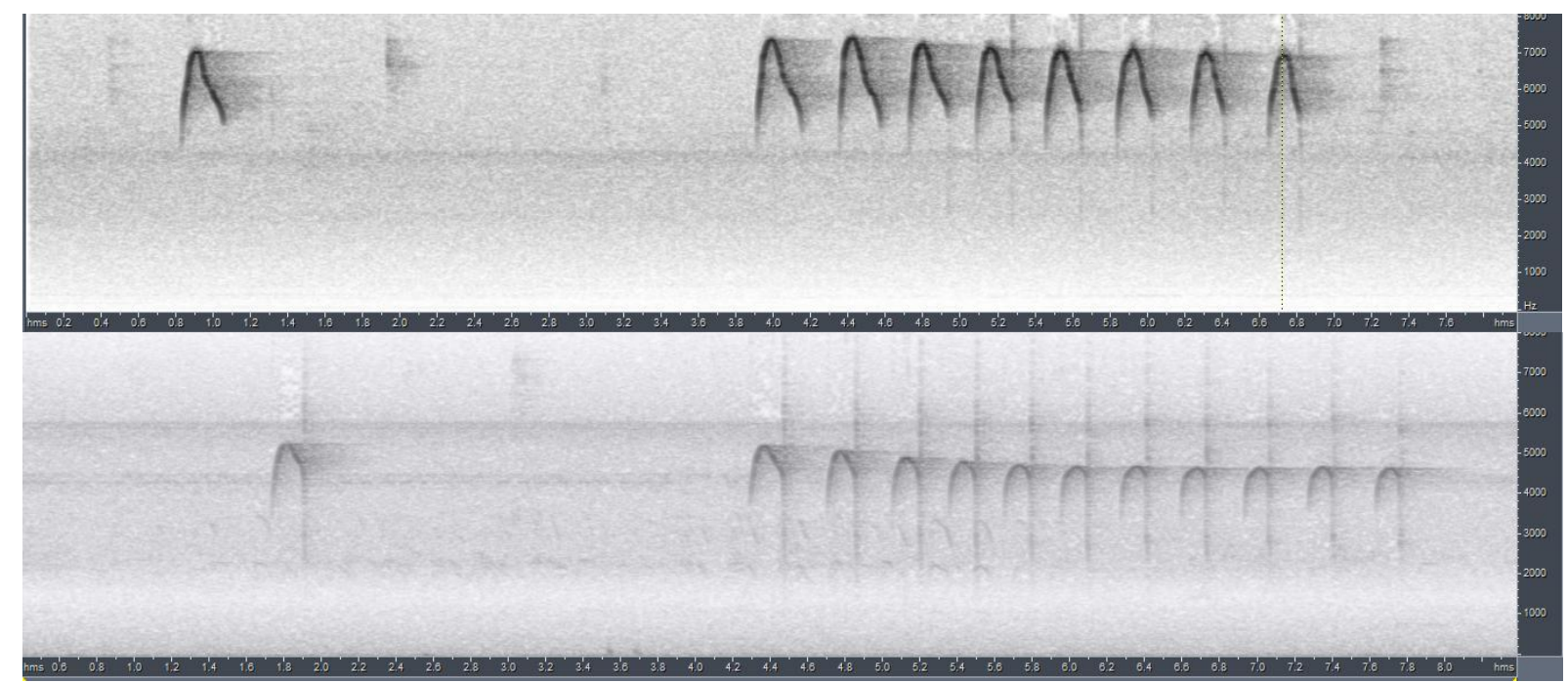

Figure 1: typical song of Group 1 (top) and group 2 (bottom) 

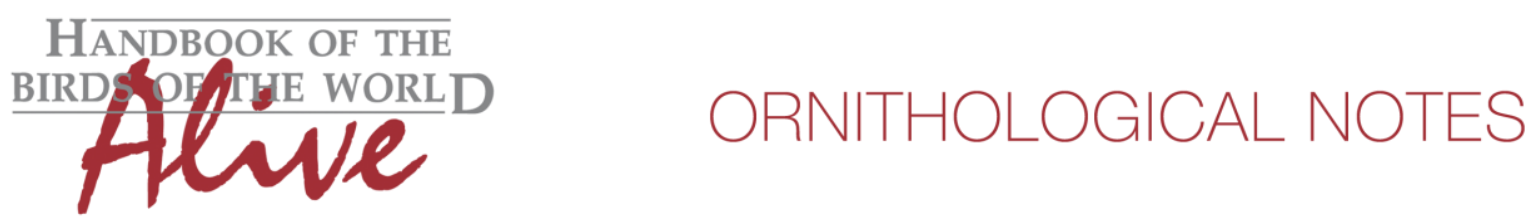

Note: recording XC4080 of La Paz, Bolivia seems to fit rather Group 1, and may be an indication that this group extends somewhat further south (or alternatively that there is a hybrid zone where both groups meet, see also http://www.xeno-canto.org/forum/topic/12389)

Group 2 differs from Group 1 in having lower-pitched notes (score 3) which are slightly shorter (score 1-2). Fast note series tend to be delivered at a slightly higher pace (and seem to have slightly more notes) (score 1-2). When applying Tobias criteria this would lead to a total vocal score of about 4.

This note was finalized on 19th August 2015, using sound recordings available on-line at that moment. We would like to thank in particular the many sound recordists who placed their recordings for this species on XC.

\section{References}

Tobias, J.A., Seddon, N., Spottiswoode, C.N., Pilgrim, J.D., Fishpool, L.D.C. \& Collar, N.J. (2010). Quantitative criteria for species delimitation. Ibis 152(4): 724-746.

\section{Recommended citation}

Boesman, P. (2016). Notes on the vocalizations of Rough-legged Tyrannulet (Phyllomyias burmeisteri). HBW Alive Ornithological Note 137. In: Handbook of the Birds of the World Alive. Lynx Edicions, Barcelona. (retrieved from http://www.hbw.com/node/932060 on 10 August 2016). 